\title{
DER STURM SANATÇILARININ GÖZÜNDEN HERWARTH WALDEN
}

\author{
Zeynep ÇUHADAR* \\ Seza SINANLAR USLU**
}

\begin{abstract}
Özet
20. yüzyıl Almanya'sının sanat ortamını oluşturan önemli kimliklerinden birisi de Herwarth Walden'dir (1878-1941). Walden'in 1910 y1lında Berlin'de kurmuş olduğu kültür sanat dergisi Der Sturm (1910-1932), ilerleyen yıllarda etrafinda gelişen diğer özgün sanat hareketleriyle birlikte bașta dışavurumculuk olmak üzere, Avrupa'da avangard sanatın görünürlüğünü arttıran önemli temsil ortamları oluşturur. Walden 1912 yılında dergiye bir de galeri ekleyerek dönemin avangard sanatçılarını aynı çatı altında toplar ve ses getiren önemli sergiler düzenler. Zaman içinde bir yayınevi, bir sanat birliği, bir tiyatro ve bir sanat okulunu da bünyesine ekleyerek Sturm altında çoğalmıştır. Der Sturm galerisinde gerçekleştirilen sergilerin dışında düzenlenen, sanat akşamları ve tiyatro temsilleriyle, 20.yüzyıl Almanya'sında avangard sanatın ulusal ve uluslararası görünürlük kazandığı önemli bir platform oluşturmuştur. Zira o dönemde avangard sanatı destekleyen kişi sayısı çok azdır. Walden böyle bir ortamda tüm gücüyle avangard sanatı ve sanatçısını desteklemiştir. Dönemin önemli sanatçıları da Walden Portreleriyle adeta bu desteğe teşekkürlerini sunar gibi sanat eserlerinde Walden'i anıtsal bir figür haline dönüştürmüş ve çalışmalarında ölümsüzleştirmişlerdir. Herwarth Walden sadece Almanya ve Avrupa'da sanatı etkilemekle kalmaz, aynı zamanda burada açtı̆̆ sergileri Amerika ve Japonya'ya da taşır ve bu ülkelerin farklı şehirlerinde sergiler gerçekleştirir. Edebiyat ve görsel sanat alanlarında önemli çalışmalara imza atan sanatçıları destekleyen Walden, bu sayede birçok genç sanatçının dönüşen yeni sanat ortamında görünürlük kazanmasını sağlar. Nitekim çok sayıda sanatçının makalesi ilk kez Der Sturm Dergisi'nde yayımlanır ve sanat eserleri Sturm Galerisi'nde sergilenir. Walden sanata ve sanatçılara verdiği destekle sanat ortamında adından her zaman söz ettiren bir kişi olmuştur. Bu çalışmada Türk Sanat Tarihi içinde adına az rastlanan 20. yüzyılda modern sanatın önemli temsil ortamlarını oluşturan Alman müzisyen, besteci, yazar, sanat eleştirmeni, dergi ve galeri sahibi Herwarth Walden ve Der Sturm Hareketi'ne dair bileşenler ortaya konmaya çalışılmıştır. Bununla beraber, Walden'in farklı dönemlerde, dönemin önemli sanatçıları tarafından yapılmış portrelerinin incelendiği çalışmada ortaya çıkan eserler birleştiğinde, dönemin sanat piyasasının önemli bir figürünün bütünlüklü bir portresi ortaya çıkartılmıştır.
\end{abstract}

Anahtar Kelimeler: Der Sturm Dergisi, Herwarth Walden, Portre, Avangard Sanat, Dışavurumculuk.

* Arş. Gör., Beykoz Üniversitesi, Sanat ve Tasarım Fakültesi, Çizgi Film ve Animasyon Bölümü, zeynepcuhadar@beykoz.edu.tr

** Doç. Dr., Yıldız Teknik Üniversitesi, Sanat ve Tasarım Fakültesi, Sanat Bölümü, sinanlar@yildiz.edu.tr

Bu makale Yıldız Teknik Üniversitesi Sosyal Bilimler Enstitüsü’nde, Sanat ve Tasarım Yüksek Lisans Programına bağll olarak, Doç. Dr. Seza SINANLAR USLU danışmanlı̆̆ında, Arş. Gör. Zeynep ÇUHADAR tarafindan yazılan 'Avrupa'da Modernizmin Temsil Ortami: Der Sturm (1910-1932)' başllkl yüksek lisans tezinden üretilmiştir. 


\title{
HERWARTH WALDEN FROM THE EYES OF DER STURM ARTISTS
}

\begin{abstract}
Herwarth Walden (1878-1941) is one of the most important people, who creates the 20th centuries art scene in Germany. Der Sturm (1910-1932), the culture art magazine that he founded in 1910 in Berlin, creates important representation environments that increase the visibility of avantgarde art in Europe, especially in expressionism, along with other original art movements that have been developing in the following years. In 1912, Walden added an art gallery to the magazine, gathering the avantgarde artists of the period under the same roof, and organized important exhibitions. In time, a publishing house, a theatre, an art association and an art school were added to the structure of Sturm. Apart from the exhibitions held in the Der Sturm gallery, with the art evenings and theatrical representations, the avantgarde art in the twentieth century created an important national and international visibility. Because there were very few people who supported avantgarde art at that time. In such an environment, Walden supported his avantgarde art and artists with all his might. The important artists of the period, like Walden's portraits, thanks to this support and transformed Walden into a monumental figure in art works and immortalized them in their works. Herwarth Walden not only influences art in Germany and Europe, but also exhibits in the USA and Japan and exhibits in different cities of these countries. Supporting artists who have made significant contributions to literature and visual art, Walden enables many young artists to gain visibility in the transforming new art scene. As a matter of fact, a large number of artists' articles have been published for the first time in the Der Sturm Magazine and art works are exhibited in the Sturm Gallery. Walden has always been a name in the art scene with the support of art and artists. In this study, it was tried to reveal the components of German musician, composer, writer, art critic, journal and gallery owner Herwarth Walden and Der Sturm Movement, which had created important representations of modern art in the 20th century, that rarely have a part in Turkish Art History. However, when Walden's works, which were examined in different periods, and his portraits made by prominent artists of the period, came together, a complete portrait of an important figure in the art market of the period was unearthed.
\end{abstract}

Keywords: Der Sturm Magazine, Herwarth Walden, Portrait, Avantgarde Art, Expressionism.

\section{Giriş}

20. yüzyıl tüm dünya için ses getirici olayların, savaşların ve devrimlerin sonucunda ortaya çıkan dönüşümlerin ve etkilerinin derinden yaşandığı önemli bir yüzyıldır. 18. yüzyıl ortalarında temelleri atılan Endüstri Devrimi, devrimin sonrasında yaşanan gelişmeler ve modernleşme süreci yeni bir dönemin başlangıcı olur. Devrimle başlayan dönüşüm 19. ve 20. yüzyılda her alanı etkisi altına alır ve bu süreçte adeta ezberleri bozduran birçok yenilik ve dönüşüm hayatın her alanına etki eder. Kuşkusuz bu dönüşümün sanatı etkilememesi beklenemezdi. 19. yüzyıl Batı sanatında tanık olunan geleneksel sanata karşı yapılan başkaldırı, 20. yüzyıl sanatının oluşmasında önemli bir rol oynar. Salon Sergileri ve onlara alternatif olarak açılan 'Reddedilenler Salonu' sanatta durdurulamaz bir dönüşümün başlangıcı olur. Avangard sanat hızlı bir yükselişe geçer ve izleyicisine artık hitap etmeyen akademik sanatın yerini alır. Yükselen bir ivmeyle devam eden bu öncü hareket, döneme damgasını vuran eserlerin ortaya çıkmasına vesile olur.

19.yüzyıl Avrupa'sında başlayan bu dönüşüm hareketleri, 20. yüzyıl sanatının oluşumunun başlıca nedenleri arasındadır. Sanatçılar da bu yeni modern dünyanın görüntüsünü geleneksel yaklaşımın 
tersine yeni bir anlayıșla izleyiciye yansıtırlar. Bunu yeni ve gündelik konuları ele almanın yanı sıra farklı teknikler ve materyaller kullanarak gerçekleştirmişlerdir. Sanatçılar, kimi zaman bir görüntüyü geleneksel yöntemde olduğu gibi birebir yansıtmak yerine, kendi içsel duygularını, düşüncelerini ve hayallerini farklı teknikler kullanarak çalışmalarında konu edinmişlerdir. Nitekim portre sanatı da bu anlayıştan nasibini alır. 16.-17. yüzyıllarda karşımıza çıkan ve sipariş üzerine yapılan portreler sanatçılar tarafindan uzun sürelerde tamamlanan ve birebir tuvale aktarılan geleneksel portre anlayışıyla yapılmış portre örneklerinden oluşurken, 19. yüzyıla bakıldığında fotoğrafın icadıyla değişime uğrayan sanat anlayışının portre sanatında da kendini önemli ölçüde gösterdiği görülmektedir. Artık sanatçılar resmettikleri modellerin portrelerini, birebir yapmak yerine farklı renk armonileri kullanarak kendi içsel yaklaşımlarını ve kimi zaman modellerinin duygu durumlarını da işin içine katarak çalışmalarına yeni bir bakış açısı kazandırmışlardır. Bununla beraber sanatçılar yansıttıkları bu duygu durumlarını kendilerine özgü bir anlayışla betimlemeyi tercih ederler. Tüm bu sebepler göz önüne alındığında, 20. yüzyılda geleneksel portre anlayışının yerini alan yeni porte sanatı, oldukça dikkat çekicidir ve bu anlayışla resmedilen portre örneklerinin sayısı oldukça fazladır.

Böylesi bir ortamda sanatın yeni temsil ortamlarına ihtiyacının gerekliliğini söylemek gerekecektir. Yazının başında da değinildiği üzere bu sergilerin başlangıcını Salon Sergileri oluşturmuştur. Salonlar yapıldıkları dönemin sanatını yansıtan en önemli platformlardır ve güncel sanatı sergileyen önemli mekânların başında gelmektedirler. Zamanla etkinliğini kaybeden salonlarla birlikte sanatta yaşanan dönüşüm, alternatif sergi alanlarının doğmasına sebep olur. Salonlara alternatif olarak gerçekleştirilen sergilerle birlikte Avrupa'da çok sayıda yeni sergi alanları ortaya çıkar. İlerleyen süreçte Almanya'nın başkenti Berlin, yükselen avangard hareketinin merkezlerinden biri olur. 20. yüzyılın başında şehirde çok sayıda yeni sergi alanları ortaya çıkar. Sheppard'ın da bahsettiği gibi yaklaşık on yıllık bir süreçte Berlin dişavurumculuğun merkezi haline gelir (Sheppard, 2009, s.244). Avangard sanatın, dışavurumculuk özelinde Almanya'da tanıtıldığı başlıca sergi alanı ise Sturm Galeri'dir. Alman müzisyen, besteci, yazar, sanat eleştirmeni, koleksiyoner, dergi ve sanat galerisi sahibi Herwarth Walden (1878-1941), 20. yüzyıl Avrupa'sında avangard sanatın en önemli temsilcilerindendir. 1910 yılında Berlin'de yayım hayatına başlayan haftalık kültür ve sanat dergisi Der Sturm'un (1910-1932) kuruculuğu ve yayımcıllğını üstlenir. 1912 yılında ise dergiyle aynı adı taşıyan Sturm Galeri'yi kurar.

\section{Herwarth Walden ve Der Sturm Hareketi}

1900'lerin başında adını Herwarth Walden olarak değiştiren ve ilk adı Georg Lewin olan Walden, 16 Eylül 1878 yılında Berlin'de dünyaya gelir. Walden'in ilk eşi avangard ve dişavurumcu şair Else Lasker-Schüler, Amerikalı yazar ve filozof Henry David Thoreaus (1817-1862)'un Walden; or, Life in the Woods (1854) isimli romanından esinlenerek Walden'e bu ismi takar (Schreyer, 1956, s. 8). Babası doktor Viktor Lewin ve annesi Emma Rosenthal'ın üç çocuğundan ilkidir. Walden (Lewin) Leibniz-Gymnasiums - Leibniz Lisesi'nde okurken Conrad Ansorge'den piyano ve Heinrich Hofmann'dan kompozisyon dersleri alır. Müziğe olan ilgisi ve başarısı sayesinde 1897 yılında Liszt bursu kazanmış ve İtalya'nın Floransa kentinde iki sene piyano eğitimi alma şansına sahip olur (Vierhaus, 2008, s. 370). 


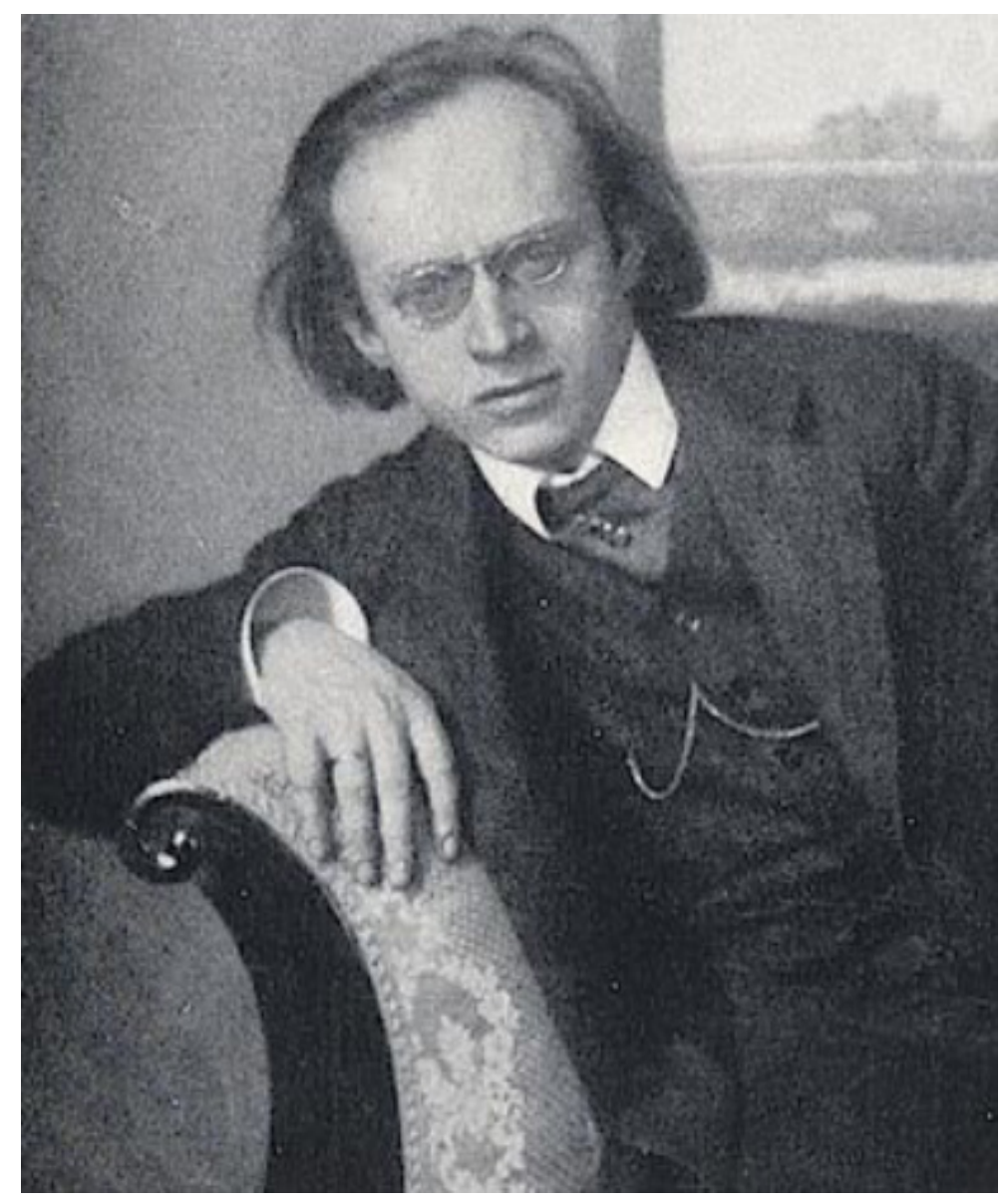

Resim 1: Herwarth Walden, 1910.

1910 yılında Berlin'de kurmuş olduğu kültür sanat dergisi Der Sturm (1910-1932), ilerleyen y1llarda etrafında gelişen diğer özgün sanat hareketleriyle birlikte başta dişavurumculuk olmak üzere Avrupa'da avangard sanatın görünürlüğünü arttıran önemli temsil ortamları oluşturur. Walden 1912 yılında dergiye bir de galeri ekleyerek dönemin avangard sanatçılarını aynı çatı altında toplar ve ses getiren önemli sergiler düzenler. Zaman içinde bir yayınevi, bir sanat galerisi, bir sanat birliği, bir tiyatro ve bir sanat okulunu da bünyesine ekleyerek Sturm çatısını genişletir. Der Sturm galerisinde gerçekleştirilen sergilerin dışında düzenlenen sanat akşamları ve tiyatro temsilleriyle, 20. yüzyıl Almanya'sında avangard sanatın ulusal ve uluslararası görünürlük kazandığı önemli bir platform oluşturmuştur.

Walden, bahsedildiği üzere 1912 yılında Berlin'de kurduğu Sturm Sanat Galeri’siyle dönemin sanat ortamında oldukça ses getiren önemli sergiler düzenlemiş̧tir. Bu sayede dönemin farklı stillerde çalışmalar ortaya koyan birçok genç sanatçının görünürlük kazanmalarında Walden ve Sturm Galerisi önemli bir rol oynamıştır. Nitekim Sturm sanatçılarından bazıları ileride çok ünlü isimler olacaklardır. Eleştirmen L.H. Leitzel (1917, s.153), 1917 yılındaki yazısında Der Sturm'dan şu şekilde bahsetmektedir:

"Der Sturm ilk önce, kırılmamış yaşamın içinde firtınalı bir şekilde vuran bir kalp. İçinde olağanüstü bir sanat coşkusu ve mutlu yaratıcllı̆̆n parladiğı bir kalp. Bir kalp ve birçok insan. Birçok sanatçı ve tüm uzuvlarda aynı kalp atışını hissettiğiniz 
bir vücut, bazen güçlü, bazen zaylf. Çünkü, her şeyden önce, Der Sturm bir inançtır. [...] Sanat gökyüzü üzerinde firtına, uyuşuk suları çırparak, yaşll, zayıf ağaçların yapraklarını ve çürük bedenlerini ikiye ayırarak, kaybolan hazineleri ortaya çıkarmaya çalışırken, hastalıklı ışıkları söndürür ve güçlü olanları, toprak altında kalanları ışıltıyla parlatır."

Herwarth Walden görünmeyeni, belki de o zamana kadar dikkat çekmeyeni gün yüzüne çıkartır. Sanatçılara verdiği bu destek ve inançla dönemin sanatının ve sanatçısının bir araya geldiği beraber sanat anlayışlarını paylaşabildikleri bir ortam oluşturmuştur. Bu sayede dönemin yeni sanatının izleyiciye ulaşması sağlanmış, eleştirel bakış açısıyla sanatın farklı yönlerini halka sunulmuştur.

Der Sturm ve Herwarth Walden, derginin adının anlamı gibi Avrupa' da adeta yeni bir firtına estirmiştir. Walden'in yakın dostu olarak bilinen ve Der Sturm bünyesinde önemli çalışmalar gerçekleştiren Alman sanatçı, yazar, editör ve sahne tasarımcısı Lothar Schreyer (1886-1966), 1956 yılında kaleme aldığ 1 Erinnerungen an Sturm und Bauhaus - Sturm ve Bauhaus'u Hatırlamak isimli kitabında, Was ist Der Sturm? - Der Sturm nedir? Sorusuna Alman dişavurumcu şair ve oyun yazarı August Stramm'in (1874-1915) sözleriyle: "Der Sturm Herwarth Walden'dir" (Schreyer,1956, s.7) cevabını bizlere aktarmaktadır. Walden'in ilk günden son güne kadar Der Sturm için yoğun bir şekilde çalıştığını ifade eden Schreyer (1956, s.7), Walden ve Der Sturm için şu sözleri söyler:

“O aynı zamanda Avrupa sanatının dönüşümünün dönüm noktasıydı. 20. yüzyılın ilk on yılının sanat dönüşümünde önem taşıyan sanatçılarının karşı koyamayacakları bir mıknatıstı. Bu miknatıs bir insand,, Herwarth Walden. Farklı ülkelerden gelen Dışavurumculuk, Fütürizm, Kübizm'i temsil eden sanatçılar kendilerini gerçekten güvenerek teslim ederken biliyorlardı $\mathrm{ki}$ bu adam onları gerçekten tanıyor ve bu sanatçıları ve çalışmalarını yürütmek için değil aynı zamanda onları zafere götürebilme yeteneğine sahip olduğunu biliyorlardl. Herwarth Walden, hedefine ulaşana kadar tüm yaşamını kayıtsız şartsız ortaya koydu."

Sanatçıların Herwarth Walden'le olan ilişkilerinin güven temelinde oluştuğu görülmektedir. Bununla beraber Walden, sadece Der Sturm bünyesindeki sanatçıların çalışmalarını sergileyip pazarlama derdinde olmadığını, aynı zamanda sanatçıların çalışmalarıyla başarı sağlamaları ve isimleriyle de sanat ortamında ön plana çıkmaları için desteklediği görülmektedir. Sanatçılar da Walden'in bu desteği sayesinde hak ettikleri başarıları sağlayacakları konusundaki inançlarını hep korumuşlardır.

Schreyer kitabında o yıllardan bahsederken, Walden ve birçok yakın arkadaşıyla on iki yıldan fazla çalıştı̆̆ını, dostluğun ve işin onları birbirine bağladığını, neşe ve kederi birlikte paylaştıkları notunu da düşmüştür (Schreyer, 1956, s. 8). Bu durumda, Der Sturm etkinlikleri, yakın dostların ve aynı zamanda çalışma arkadaşlarının birbirlerine olan desteğiyle samimi bir ortamda yürütülmüş ve geliştirilmiştir demek yanlış olmayacaktır.

Walden (1910, s.1) derginin birinci sayfasında yer alan içerik bölümünün hemen altında Zwei Worte İki Kelime başlıklı yazısıyla daha önce çalıştığı dergilerle ilgili yaşadığı deneyimlerini ve görüşlerini şu şekilde açıklamıştır:

"Dördüncü kez kamuoyunda yeni bir dergi yayımllyoruz. Çok fazla kişi tarafindan utanç verici olarak görülen faaliyetlerimiz üç defa kaba sözleşme ihlalleriyle engellenmeye çalışılmuştır. Biz de kendi yayımcılarımı olmaya karar verdik. Ne mutlu bize ki halen daha gazetecilik ve yazı dizilerinin yerini kültür ve sanatın alabileceğine inanabiliyoruz." 
Herwarth Walden daha önceki yıllarda farklı dergilerin yayımcılık görevlerini üstlenmiş fakat bu dergilerde zor şartlar altında çalışmak durumunda kalmıştır. Der Sturm'la birlikte artık kendine ait bir derginin yayımcısı ve başyazarı olmuş, tüm enerjisini ve vaktini buradaki çalışmalarına ayırmıştır. Dergi 1932 yılında kapatılana kadar adeta Walden'in hayatı olmuştur.

Yapılan sergiler, davetler, müzik dinletileri, tiyatro temsilleriyle geçen yoğun programı sayesinde Walden sanat ve sanatçılarla hep iç içe olmuştur. İlerleyen y1llarda kimi sanatçılar da Walden'in portrelerini yapmışlardır. Bu sanatçılar arasında; Avusturyalı ressam Oskar Kokoschka (1886-1980), Fransız ressam ve sanat tarihçisi Robert Delaunay (1885-1941) Alman ressam, fotoğrafçı, sanat profesörü Edmund Kesting (1892-1970), Macar ressam Belá Kádár (1877-1956), Alman heykeltıraş, ressam ve tiyatro dekoratörü William Wauer (1866-1962), İsveçli çizer John Jon-And (1889-1941), Çek ressam ve litografi sanatçısı Emil Orlik (1870-1932), Macar ressam Hugó Scheiber (1873-1950) ve Walden'in bir dönem eşi olan Alman şair Else Lasker-Schüler (1869-1945) bulunmaktadır.

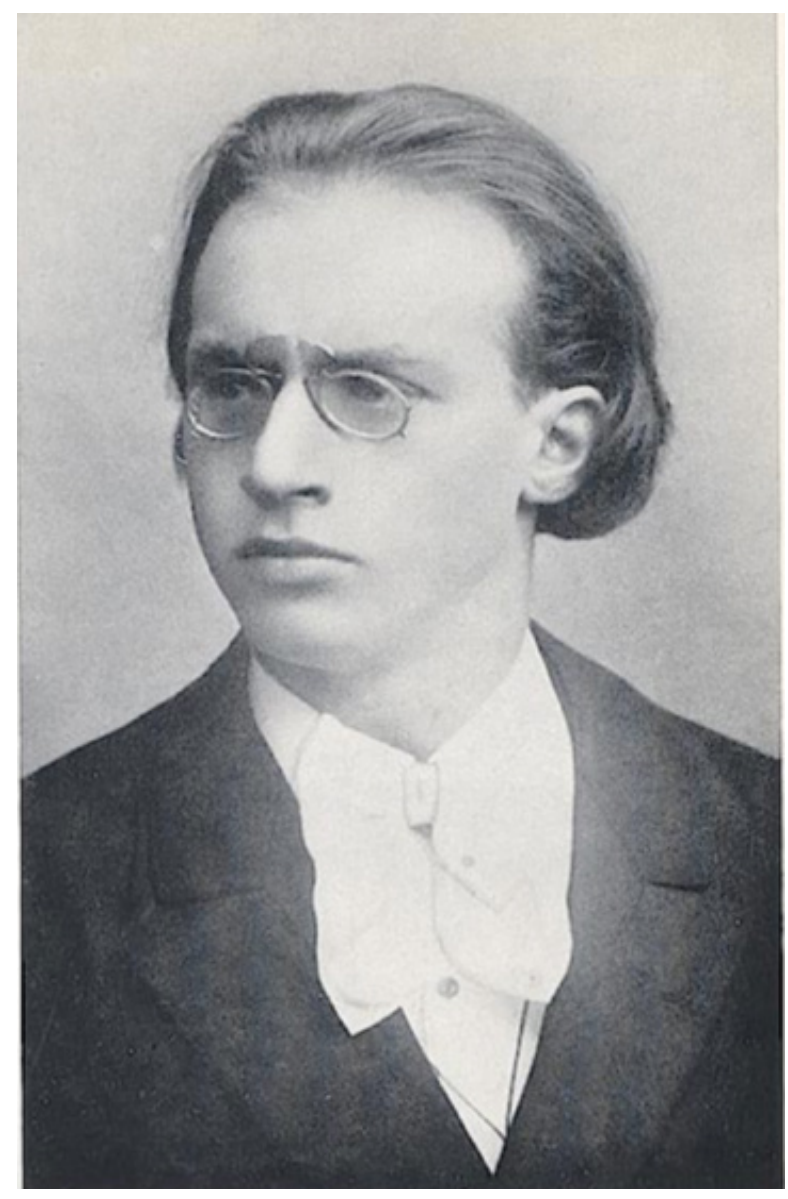

Resim 2: Herwarth Walden, 1903

Oskar Kokoschka, 3 Mart 1910 yılında yayım hayatına başlayan Der Sturm Dergisi'nin başlıca sanatçıları arasındadır. 1912 yılında Sturm Galerisi kurulmadan önceki dönemde dergide çalışmaları en fazla yayımlanan sanatçılardan biri olan Kokoschka, Walden portreleri denilince de akla ilk gelen sanatçıdır. Sanatçı'nın 1910 yılında tuval üzerine yağlıboya olarak resmettiği Herwarth Walden Portresi, günümüzde Stuttgart Devlet Müzesi'nde bulunmaktadır. Dikey kadraj olarak oluşturulan portrede, sanatçının boyayı kullanım şekli ve fırça serbestliğinden yola çıkarak tablonun dışavurumcu 
bir anlayıșla resmedildiği söylenebilir. Kahverengi ve tonlarının hakim olduğu resimde firça darbeleri açıç̧a görülmektedir. Bu darbeler izleyiciye resimde bir ritim duygusu hissettirmektedir. Walden'in müzisyen kişiliği ile ilişkilendirilebilecek olan bu devinim sayesinde, izleyicinin gözünün resmin yüzeyinde eşit bir şekilde gezmesi sağlanmıştır (Resim 3).

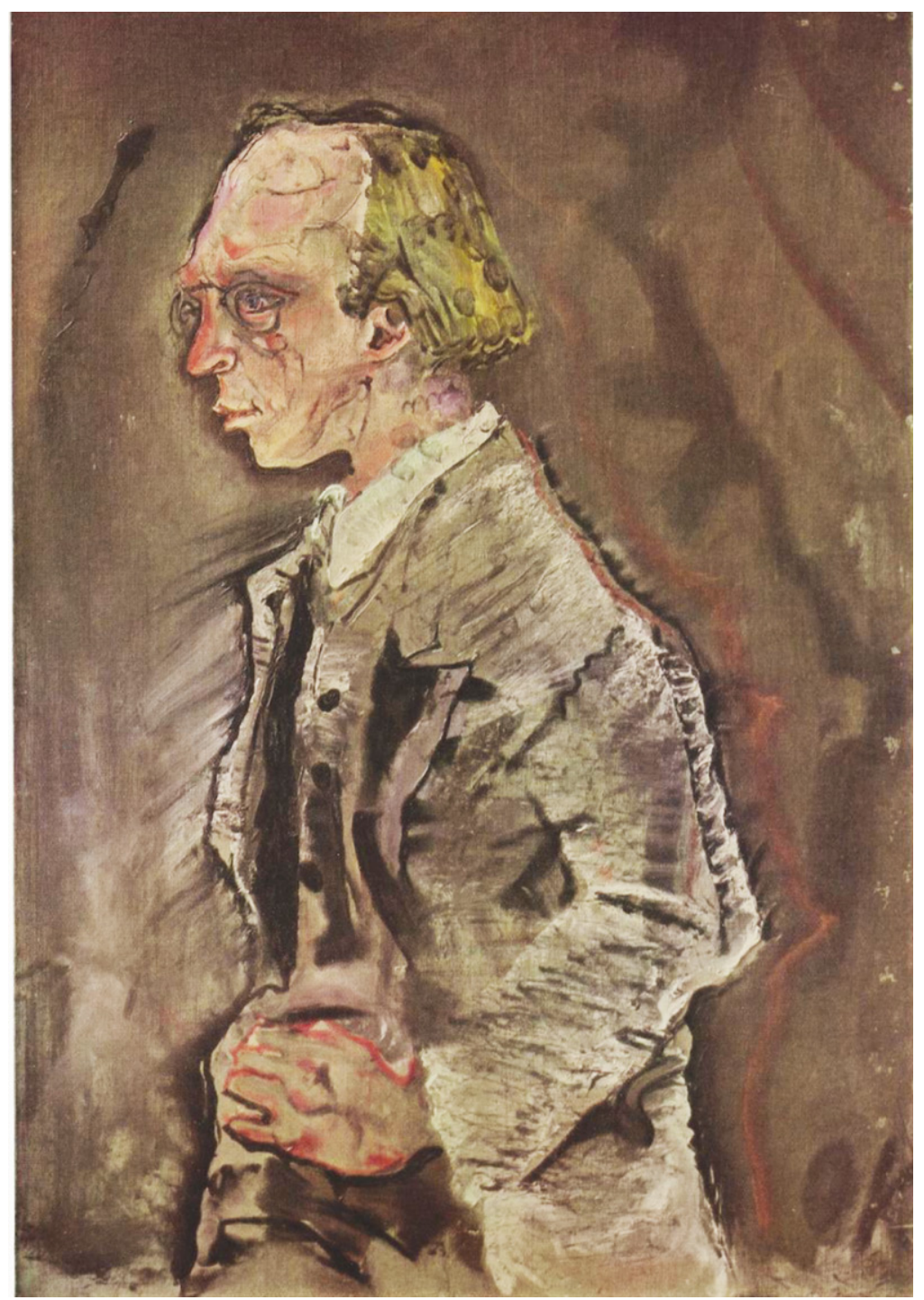

Resim 3: Oskar Kokoschka (1886-1980), 'Herwarth Walden'in Portresi', Tuval üzerine yağlı boya, 100 x 69,3 cm, 1910, Stuttgart Devlet Galerisi.

Kokoschka'nın bir diğer Herwarth Walden Portresi ise Menschenköpfe - İnsan başları ismiyle dergide bir süre düzenli yayımlanan ve dönemin şair, yazar ve akademisyenlerinin portrelerinin yer aldığ resmetmiştir. Bu portrede sanatçının yağlıboya çalışmasında (Resim 3) kullandığı firça darbelerinin yarattığı ritim benzeri bir ritmi çizgilerle yarattığı görülür. Bu çalışma, derginin 28 Temmuz 1910 yılında yayımlanan 22. sayısında yer alır ve günümüzde Berlin Ulusal Müzesi'nde bulunmaktadır (Resim 4). 


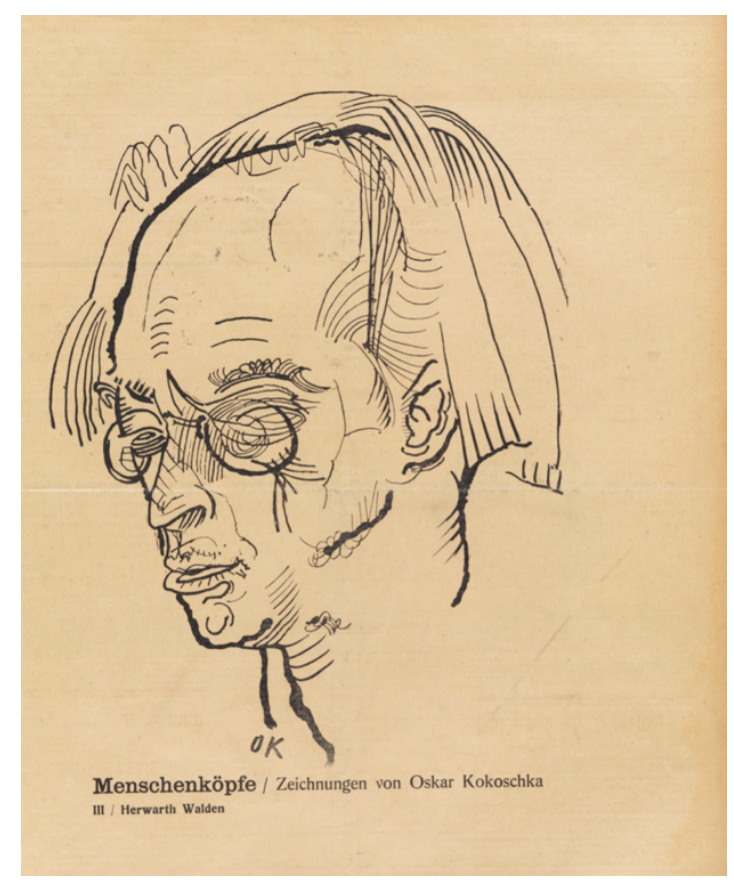

Resim: 4 Oskar Kokoschka'nın Der Sturm'da yer alan Herwarth Walden portresi.

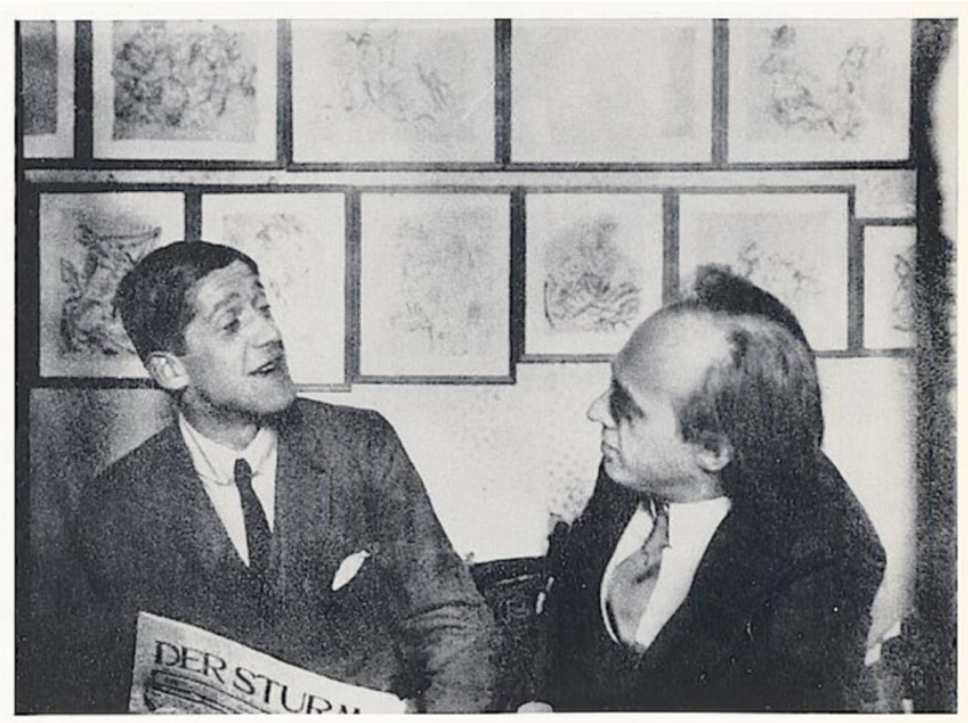

Resim 5: Oskar Kokoschka ve Herwarth Walden, Walden'lerin Berlin'deki Grafik Odası olarak isimlendirdikleri odalarında, duvardaki çizimler Kokoschka’ya ait, 1916.

İş ilişkilerinin yanı sıra iyi birer dost olan Herwarth Walden ve Kokoschka, Walden'lerin Berlin'deki evinde Grafik Odası olarak adlandırdıkları mekânlarında sık sık zaman geçirip, sanat hakkında sohbet etme firsatı bulmuşlardır. Fotoğrafta görülen odanın duvarında asılı olan çalışmaların tamamı Oskar Kokoschka'ya ait çizimlerden oluşmaktadır (Resim 5). Kokoschka, 1954 yılında Walden'le ilişkisini 
şu sözlerle anlatır: "Herwarth Walden benim için çok önemliydi. Bizi birleştiren bir ideoloji değil, tamamen sanatsal yaratma takıntısiydi" (Walden N., 1963, s. 131-132). Onları birbirlerine bağlayan sanat öylesine güçlüydü ki Kokoschka uzun yıllar Der Sturm'da çizimleri, resimleri, baskıları ve yazılarıyla yer almıştır. Çizer kimliği dışında Kokoschka dergide yardımcı editör, yazar, muhabir ve dağıtıcı olarak da görev yapmıştır (Hülsen-Esch, 2011, s. 202).

Kokoschka, özellikle dışavurumcu portreleriyle dikkat çeken bir sanatçıdır. Sanatçının 1912 yılında Viyana' da gerçekleştirdiği 'Vizyonların Doğası Üzerine' isimli konuşmasında belirttiği gibi, "Vizyonların farkında olma hali, içinde bizim hatırllyor ya da algıllyor olduğumuz bir hal değildir. Daha çok, kendi içimizdeki görüleri deneyimlediğimiz bir bilinç düzeyidir" (Chipp, 1968, s. 170). Sanatçı, görünümlerin insanların iç görülerinde deneyimlediği kendini ve çevresini tanıma yeteneği olduğunu söylemektedir. Bu sayede sanatçının sanat yaklaşımının temelinde içsel bir deneyimden yola çıktığı kavranmaktadır.

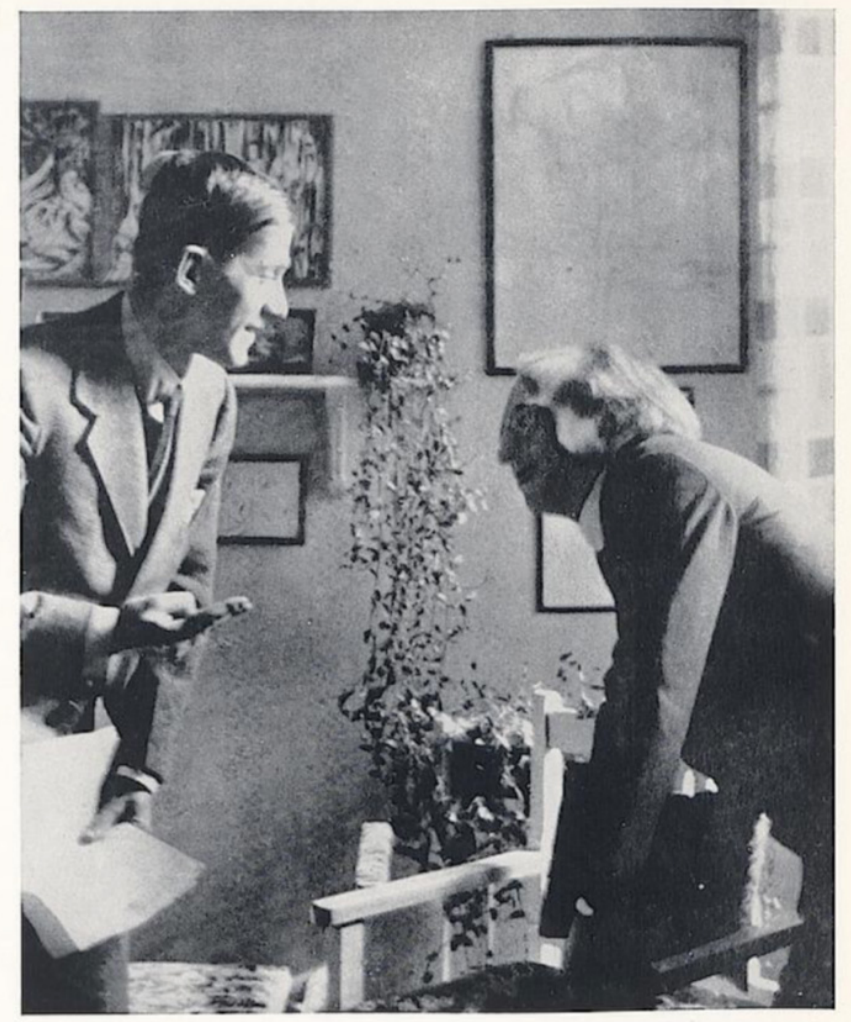

Resim 6: Oskar Kokoschka ve Herwarth Walden, Walden'lerin Berlin'deki Grafik Odası olarak isimlendirdikleri odalarında, 1916.

Walden portreleriyle tanınan bir diğer sanatçı ise, Alman ressam, fotoğrafçı ve sanat profesörü Edmund Kesting'dir. Sanatçının ilk çalışması 1921 yılında Der Sturm'da yayımlanır. Kesting'in çalışmaları da Kokoschka gibi uzun soluklu bir şekilde dergide yer alır. Kesting'in farklı malzemeler kullanarak oluşturduğu çok sayıda çalışması bulunmaktadır. Özellikle dikkati çeken çalışmaları arasında fotoğraflar yer alır. Sanatçı fotoğraflarında, ağırlıklı olarak figürlü kompozisyonlar kullanır. Figürlerin gölgelerini siyah beyaz karşıtlığıyla birleştirerek oluşturduğu ve farklı katmanlarla 
zenginleştirdiği kompozisyonları oldukça dikkat çekicidir. Çalışmalarında yer alan bu figürler genellikle dönemin sanatçı ve müzisyenlerinden oluşmaktadır.

Kesting çok sayıda Herwarth Walden portresi yapmıştır. Buradaki ilk örnek, 1932 y1lında ağaç bask1 tekniğiyle oluşturduğu Herwarth Walden portresidir (Resim 7). 1932 y1lında çizdiği bir diğer Walden portresinin ise, fotoğraf çalışmalarında kullandığı kadrajları anımsatan bir kompozisyonla kurgulandığı açıkça görülmektedir (Resim 8). Çizimde Walden'in portresi cepheden görülmektedir. Portrenin sağ kısmında yer alan alanda ise, sanatçı portrenin profil görüntüsünü kullanmıştır. Siyah ve beyaz olarak üst üste iki katman şeklinde eklediği profil görüntüleri, sanatçının fotoğraflarında kullandığı gölge katmanlarını bize anımsatır.

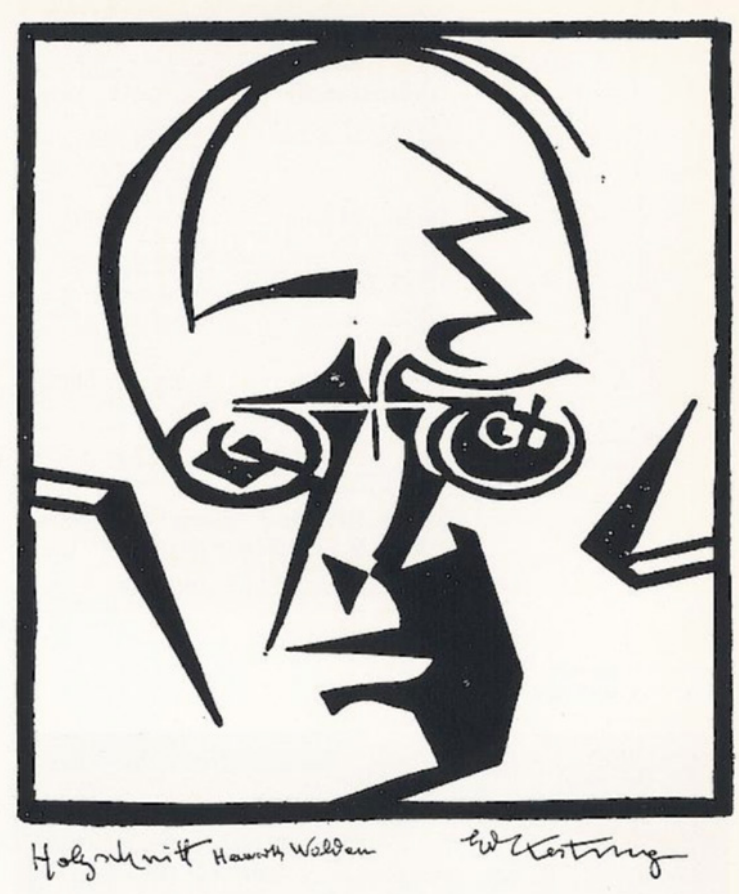

Resim 7: Edmund Kesting, Herwarth Walden Portresi, Ağaç Bask1, 1932.

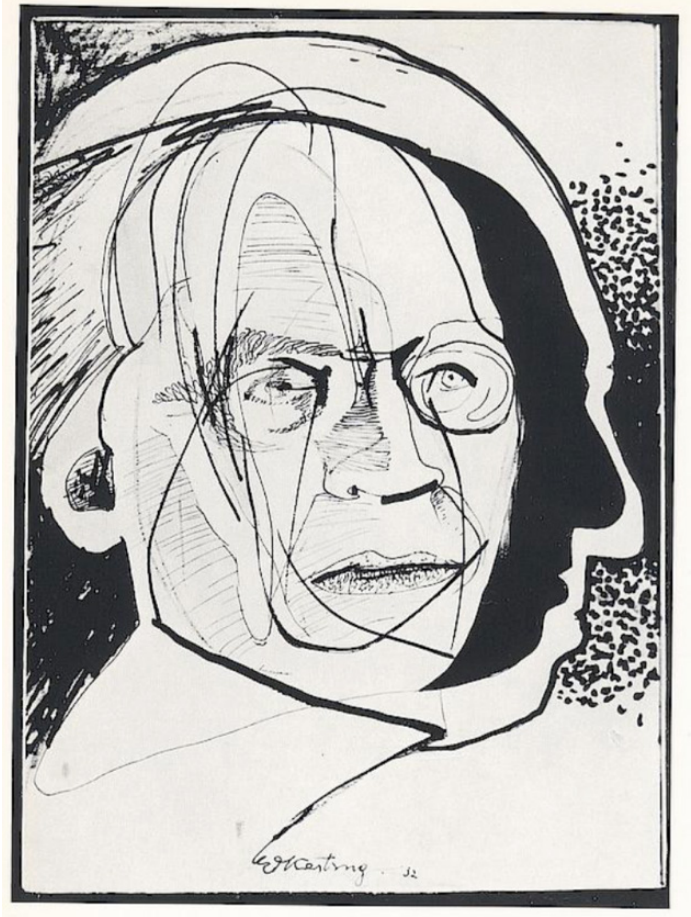

Resim 8: Edmund Kesting, Herwarth Walden, 1932.

Kesting ilerleyen yıllarda da benzer Walden portreleri gerçekleştirmiştir. Sanatçı Kesting'in genellikle siyah - beyaz zıtlıklarını kullanıldığı çizim ve baskı çalışmalarından oluşan Walden portreleri arasında renkli bir yağlı boya çalışması ve monokrom renk paletiyle oluşturduğu, içerisinde fotoğraf malzemeleriyle boyayı harmanladığı karışık teknik bir çalışması da bulunmaktadır (Resim 9-10 - 11).

Sanatçının yağlı boya çalışmasında kullandığı pentür şekli dikkat çekicidir. Kullandığı boyanın kalınlığı tuval yüzeyinde adeta bir rölyef etkisi yaratmıştır. Portrenin genelinde kullanılan sıcak sarı ve sanatçının portrede her iki gözde de uyguladığ 1 farklı biçim ve renk etkisi ilgi çekicidir. Tabloda kullanılan detaylar titizlikle düşünülmüş ve ince bir işçilikle uygulanmıştır ( Resim 9 -10). 


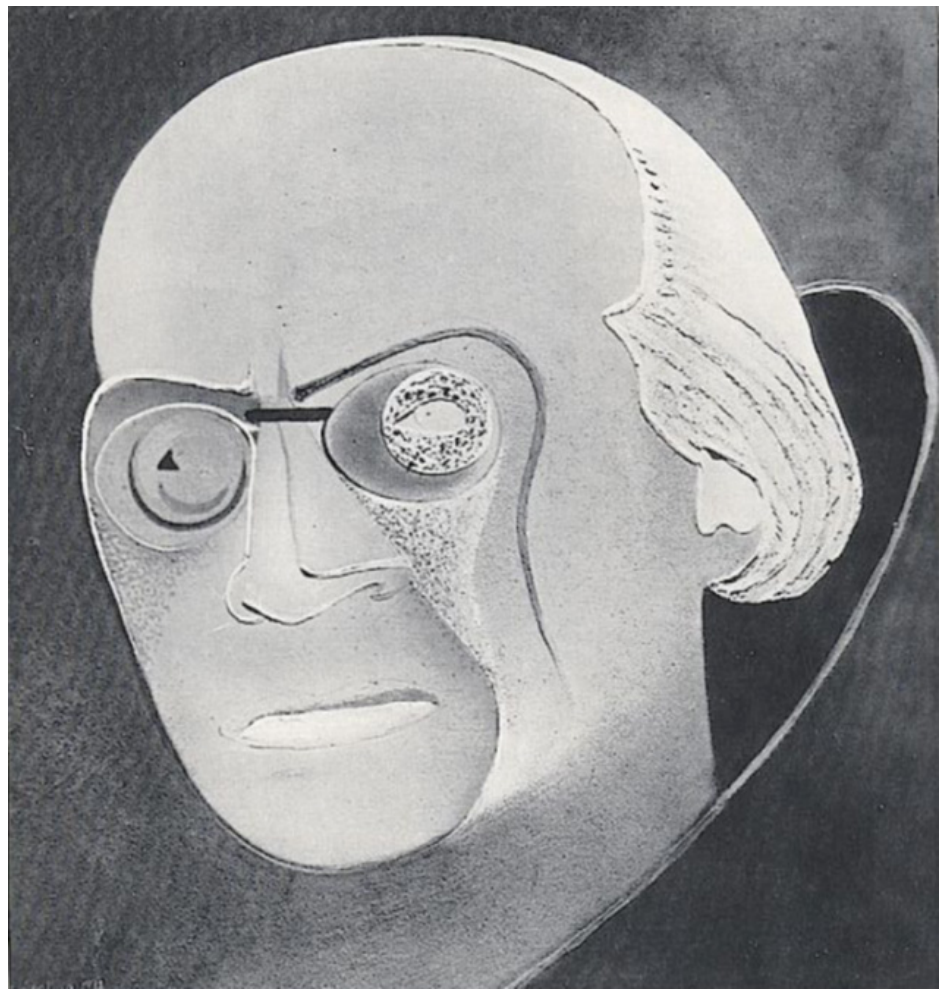

Resim 9: Edmund Kesting, Herwarth Walden, 48.5 x 43.5 cm, Karton üzerine yağlı boya, 1932.

3 Mart - 10 Haziran 2012 tarihleri arasında Almanya'nın Wuppertal kentinde Von der Heydt Müzesi'nde Avangardın Merkezi: Der Sturm adıyla bir sergi düzenlenmiştir. Sergide Der Sturm'un tarihsel süreci anlatılırken, Sturm sanatçılarının çalışmaları ve onların gerçekleştirdiği Walden portreleri de sergilenmiştir (Resim 10).

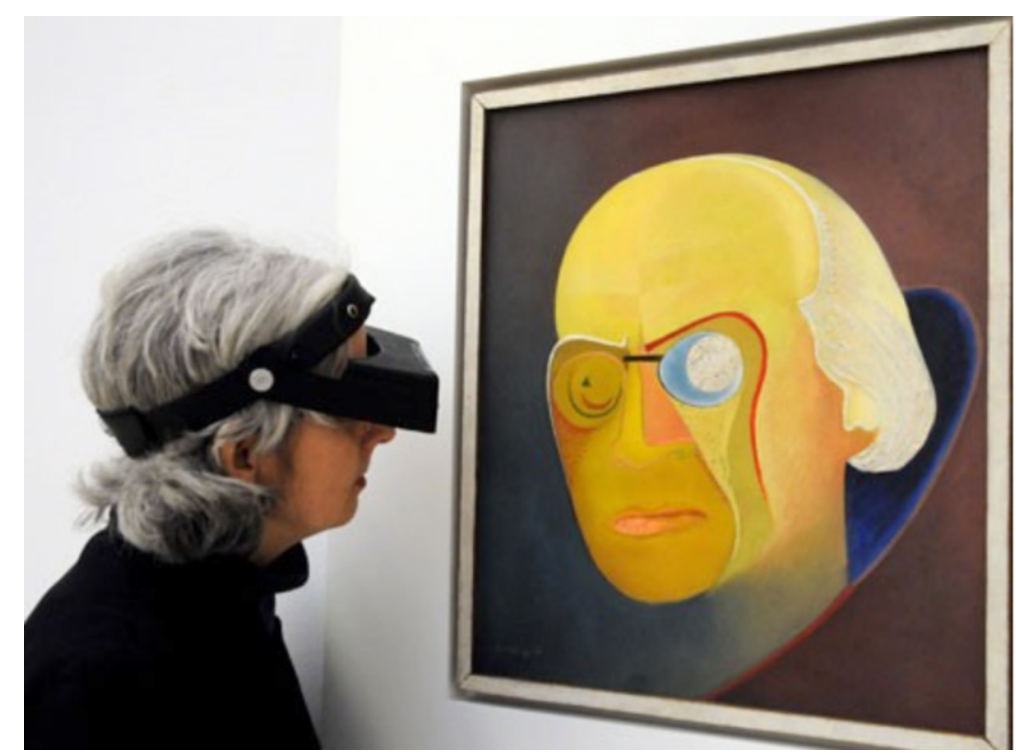

Resim 10: Sanatçı Edmund Kesting’in yağlı boya Herwarth Walden Portresi. Avangardın Merkezi: Der Sturm Sergisi, Von der Heydt Müzesi, Wuppertal Almanya, 2012. 


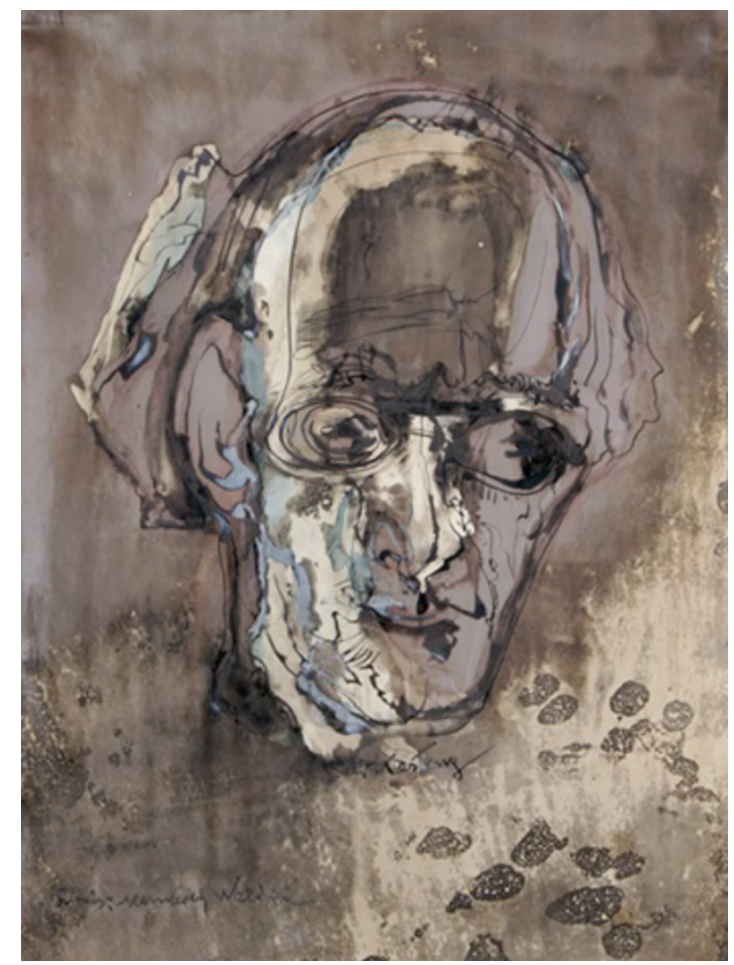

Resim: 11 Edmund Kesting, Herwarth Walden Portresi, 39,8 x 29,8 cm,

Kağıt üzerine boya ve fotoğraf materyalleri, 1949.

Fotoğrafçı kimliğiyle oluşturduğu çalışmalarıyla dikkat çeken sanatçı Edmund Kesting, bir diğer Walden portresinde fotoğraf tekniğini boyayla harmanlamış olduğu çalışmasıdır (Resim 11). Sanatçının kağıt üzerine boyayla beraber kullandığını bilinen fotoğraf malzemeleriyle oluşturduğu portre, güçlü bir anlatımla beraber soyutlamaya doğru giden karakterize edilmiş bir Herwarth Walden portresidir.

Buraya kadar incelenen Herwarth Walden'e ait portreler mürekkep, kurşun kalem, kuru boya, yağlı boya, ağaç baskı gibi farklı malzemeler kullanılarak oluşturulmuştur. Çoğunlukla siyah beyaz olarak resmedilen portreler arasında, renkli çalışmaların sayısının daha az olduğu görülür. Genel olarak eskiz niteliğindeki siyah beyaz çizimler izleyicide taze ve bir solukta çizilmiş hissi uyandırmaktadır.

Herwarth Walden 20. yüzyılda yenilenen, dönüşen sanatı görünür kılmak ve örgütlemek için yaşamı boyunca çalışmıştır. Kurucusu olduğu Der Sturm Dergisi, uzunca bir süre Avrupa'nın modern sanatının başlıca temsil ortamını oluşturmuş ve etrafında gelişen diğer özgün sanat hareketleriyle birlikte toplumun sanat alanındaki dönüşümü takip edebileceği önemli bir atmosfer yaratmıştır. $\mathrm{Bu}$ sayede insanlar değişen Avrupa sanatını ve sanatçısını tanıma imkânı bulmuştur. 1912 yılında dergiye bağlı olarak Berlin'de açılan Der Sturm Sanat Galerisi dönemin avangard sanatının en önemli sergi alanları arasında yer almıştır. Uzun yıllar boyunca Der Sturm Galerisi çatısı altında Berlin başta olmak üzere Almanya'nın diğer birçok şehrinde sergiler düzenlenmiştir. Bu şehirlerden bazıları arasında; Bremen, Dresden, Hamburg, Marburg, Münih, Nürnberg, Potsdam, Stuttgart ve Weimar bulunmaktadır. Bu şehirlerin yanı sıra Avrupa'da Avusturya, Belçika, İngiltere (Büyük Britanya), Polonya, İsviçre, İsveç, İtalya, Hollanda, Finlandiya gibi ülkelerde, Amerika'da Detroit, Denver, Colorado, Kansas City ve New York gibi şehirlerde ayrıca Japonya'da Tokyo ve Kioto'da çok sayıda 
sergi düzenlenmiş, bu sayede birçok sanatçının çalıșmalarını sergileyebilmesi için yeni ortamlar oluşmuştur (Walden H., 1924, s. 170-171). Walden'in bu büyük çaplı sanat platformu sayesinde genç sanatçılar da sanat ortamında yer alma şansı yakalamıştır.

Walden'e (1913, s.8) göre: "Hayat bizim için sanat değildir. Fakat sanat, hayattır". O her zaman dış dünyanın içselleștirilerek dıșa vurulması gerektiğini söylemiş ve bu şekilde yaratılan sanatın peşinde olmayı seçmiştir. Ancak o zaman sanatın sanat olacağını savunmuştur. Bu süreçte, dönemin sanatçılarıyla yakın ilişki kuran Walden, sergileri düzenleme aşamasında sanatçıların atölyelerine bizzat giderek çalışmalarını yerinde izler, yapacağı yeni sergiler için bu çalışmaları özenle seçer. İkinci eşi ressam Nell Walden anılarında Walden çiftinin Berlin'de bulunan evlerinde ve sergiler için seyahat ettikleri dönemlerde sanatçıların yazlık evlerinde ve atölyelerinde sık sık sanatçılarla bir araya geldiklerinden ve keyifli zamanlar geçirdiklerinden bahsetmektedir (Schreyer ve Walden N., 1954, s. 28-29). Bu sayede Walden'in sanatçılarla kurduğu ilişkinin güçlendiğini, sanatçıların da Walden'i farklı ortamlarda gözlemleme ve daha yakından tanıma şansı yakaladığını söylenebilir.

Der Sturm Dergisi'nin kurulma sürecinde dikkati çeken bir diğer isim de Herwarth Walden'in ilk eşi Alman edebiyatının avangard ve dışavurumcu ismi Else Lasker- Schüler'dir. Sanatçı'nın edebiyat alanındaki çalışmalarının birçoğu derginin ilk sayısından itibaren yayımlanır. Özellikle şiirleriyle dikkat çeken Schüler'in Eylül 1911 tarihli 77. Sturm sayısından itibaren kaleme aldığ 'Norveç’ten Mektuplar' isimli köşesinde çoğunlukla 'Sevgili Herwarth Walden' cümlesiyle başlayan, Walden'e ithafen yazılan mektuplar olduğu görülmektedir. Epeyce bir süre yayımlanan mektupların bazılarında Schüler'e ait çizimlerin yer aldığı görülmektedir. Bu çizimler ağıllıklı olarak anlattığı konuyla paralellik gösteren ve konuları destekleyen çizimlerdir. 1912 yılının 99. sayısındaki mektubun bir bölümünde çember içine alınmış bir Walden Portre eskizi olduğu görülür (Resim12). Karikatürize edilmiş portrenin rahatlıkla deneyimli bir elden çıktığı anlaşılmaktadır. Nitekim Schüler ve ressam Franz Marc (1880-1916)'ın ilerleyen dönemlerde birbirlerine gönderdikleri mektuplarda yazı ve çizimler yer alacaktır. (Dick, 2012, s. 6). Ayrıca Der Sturm’un 1912 yılının Eylül ayındaki 126. sayısında Marc ve Else'nin birlikte çalıştıkları görülecektir. Bu çalışma Franz Marc'ın ahşap baskısının Schüler' in Barışma isimli şiiri için özel olarak tasarladığı bir çalışmadır ve Der Sturm'un o ayki sayısının kapağında yer almıştır. Bu bilgiler ışığında Else Lasker-Schüler'in güçlü kaleminin dışında, güçlü bir deseni olduğunu söylemek yanlış olmayacaktır.

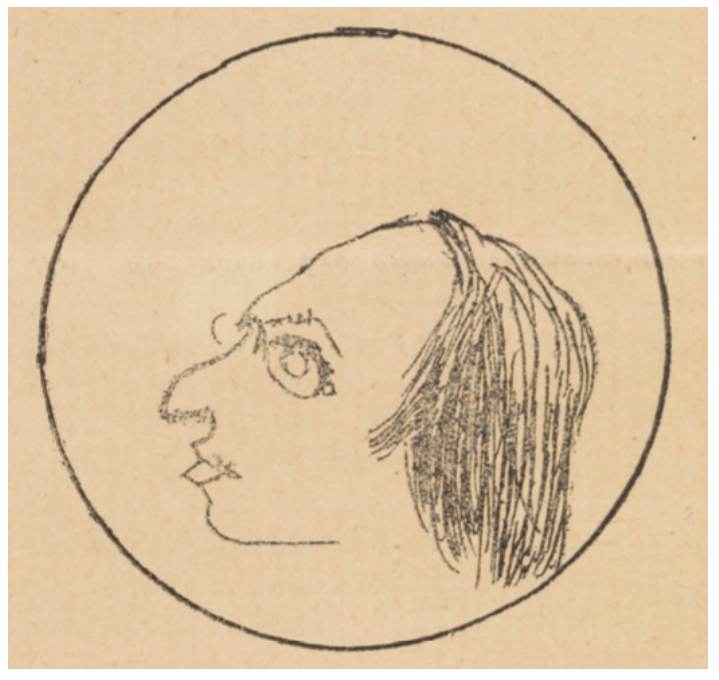

Resim 12: Else Lasker-Schüler, Herwarth Walden Portresi, 1912. 


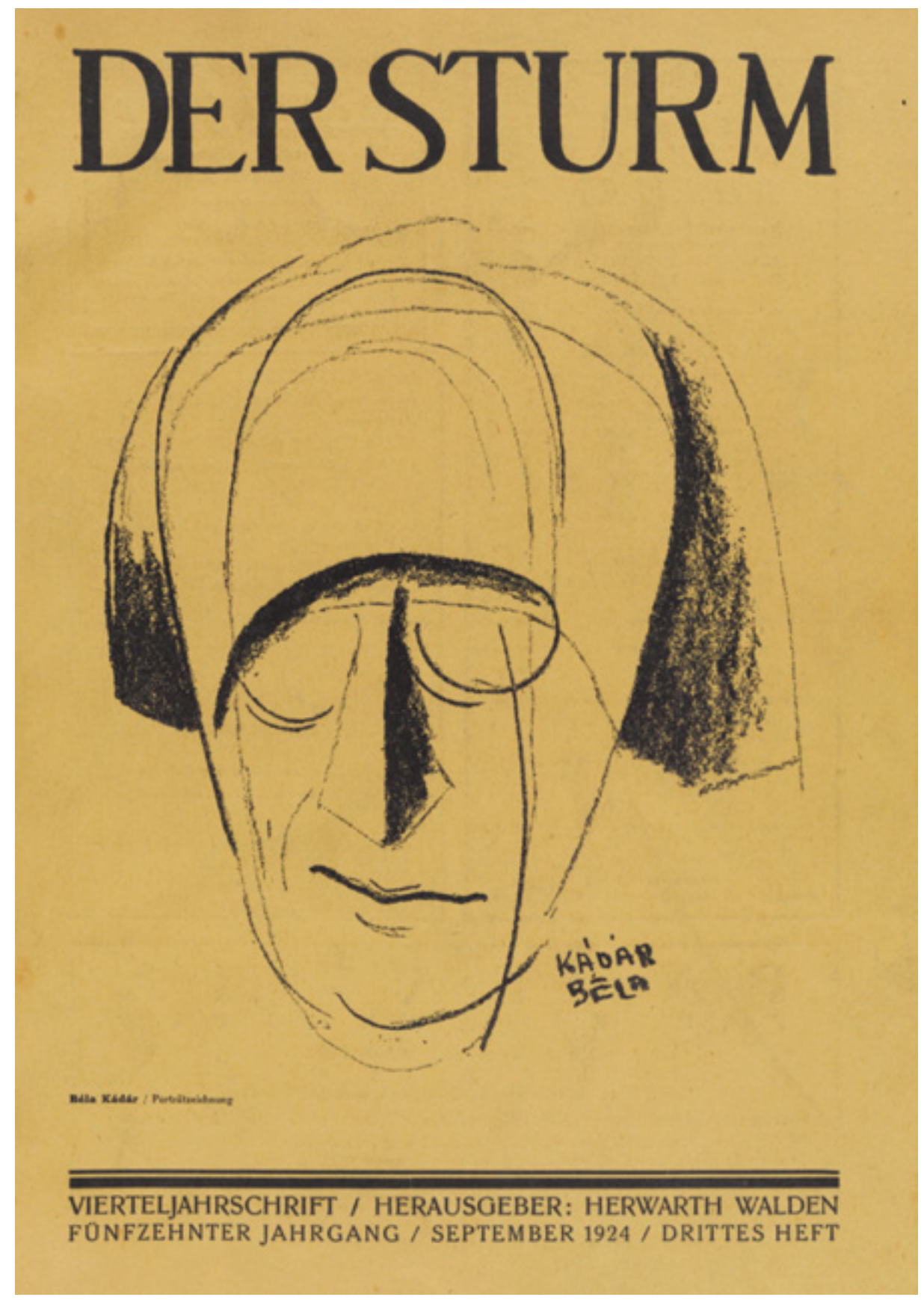

Resim 13: Béla Kádár, Herwarth Walden Portresi, 1924.

Ressam Bèla Kádár'ın Herwarth Walden Portre çalışması, Der Sturm'un 1924 y1lı 3. sayısının kapağında yer aldığı görülmektedir. Kádár'da Sturm'un önemli sanatçıları arasında yer alır. Bu çalışma o güne değin Herwarth Walden'in portresinin kapakta yer aldığı ilk çalışmadır. Litografi bask1 tekniğiyle gerçekleştirilen çalışmada sanatçı portreye belli belirsiz bir tebessüm yerleştirmiştir. Çalışmanın künyesi denilebilecek sol alt köşede yer alan sanatçının isminin bulunduğu yerin yanındaki açılamada Herwarth Walden'in adının geçmemesi çalışmanın sadece Portre Çizimi olarak belirtilmesi dikkat çekicidir (Resim 13). 


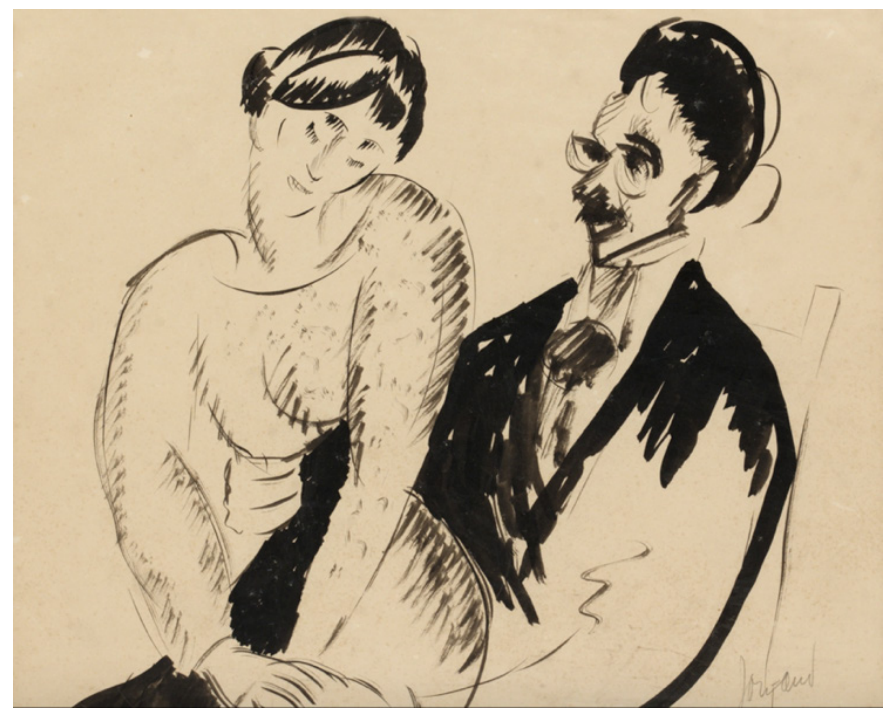

Resim 14: John Jon-And tarafindan çizilen Nell ve Herwarth Walden, 1924.

İsveçli sanatçı John Jon-And mürekkep ve pastel malzeme ile Walden Portreleri resmetmiştir (Resim 14-15). Sanatçının her iki portrede de Walden'lerin günlük hayatlarındaki bir anını yakaladığı görülür. Çalışmalar fotoğraf gerçekliğinde olmasalar da izleyiciye o anı aktarırlar. Açık koyu dengesiyle firçayı ustaca kullanan sanatçı, Nell ve Herwarth çiftinin portrelerindeki ifadeyi ve o anın duygu dolu atmosferini tüm açıklığıyla sunmaktadır (Resim 14). Sanatçının renkli Walden Portre eskizi, bir sohbet anında hızla oluşturulmuş günlük bir skeç hissi uyandırmaktadır. Renklerin sıcak soğuk dengesi ve yumuşaklığı sanatçının yorumunu destekler niteliktedir (Resim 15).

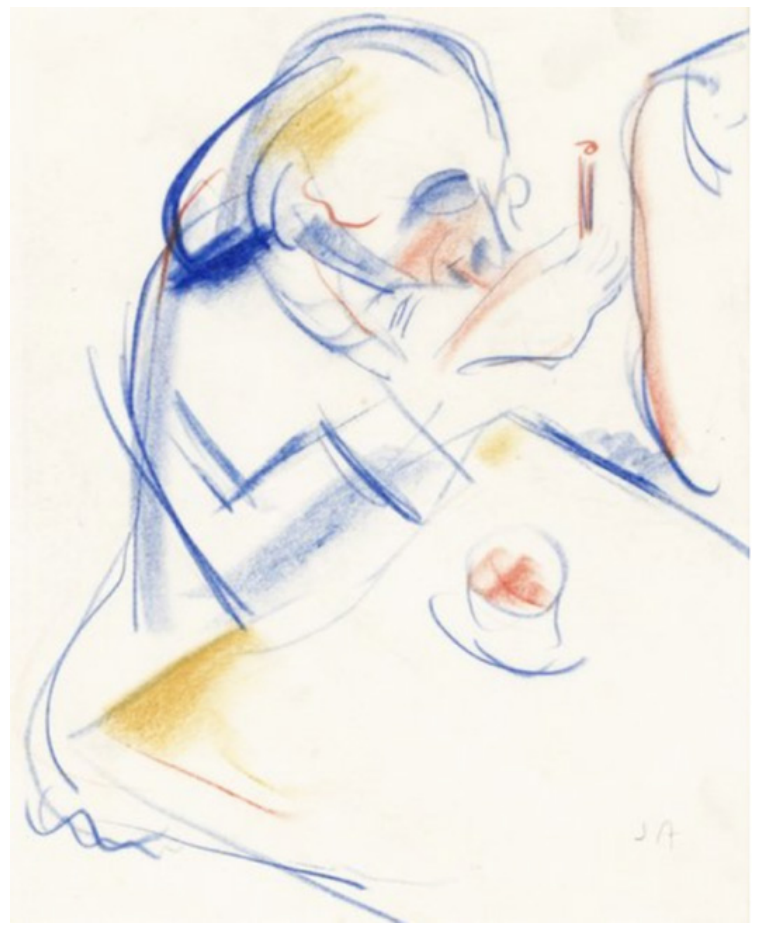

Resim 15: John Jon-And, Herwarth Walden, Pastel boya. 
Dönemin dergilerinde bask1 ve desenleriyle yer alan çizer Emil Orlik, Herwarth Walden'in bir desenini çalışmıştır (Resim 16). Serbest çizgisel araştırmanın dikkat çektiği çalışmada sanatçı, portrenin burun ve ellerinde form bozmaya yönelik bir yaklaşım sergilemiştir, bu tutum portreyi karikatür çalışmasına yaklaştırmaktadır.

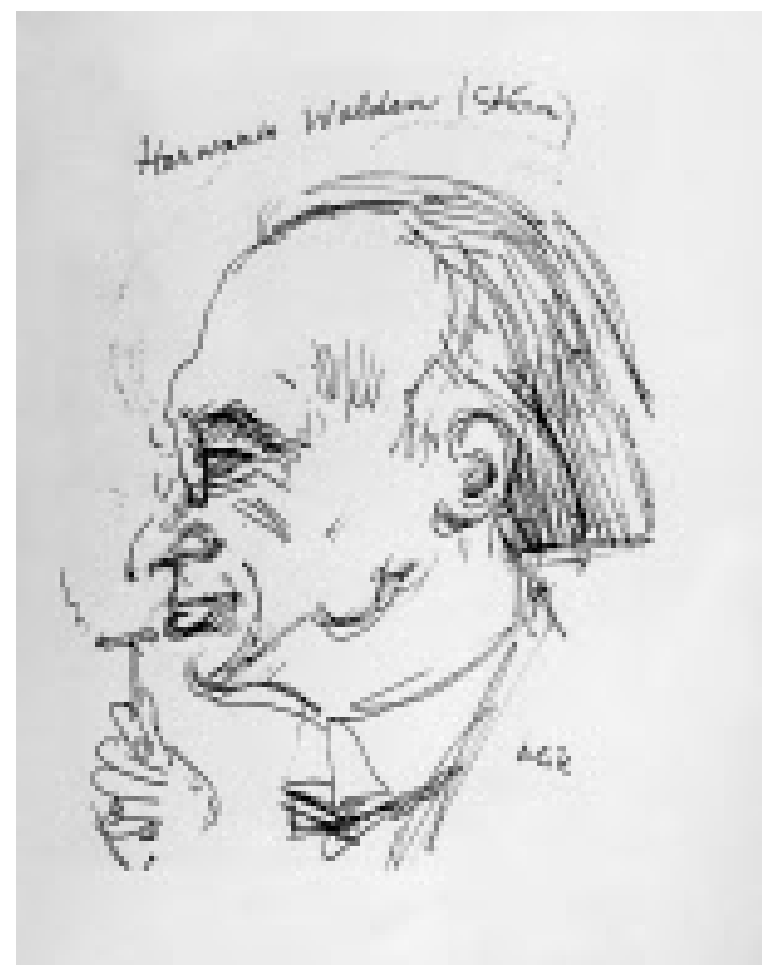

Resim 16: Emil Orlik, Herwart Walden, Portresi, 100 x 81 $\mathrm{cm}, 1923$,

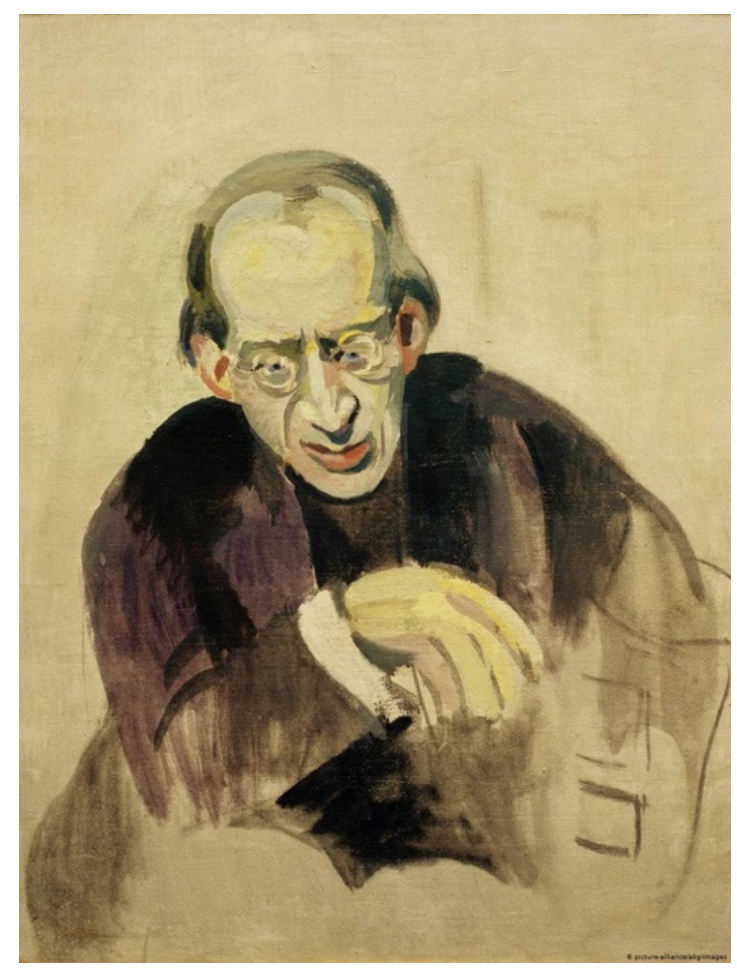

Resim 17: Robert Delaunay, Herwarth Portresi, 1926. Berlin Ulusal Müzesi

Robert Delaunay Der Strum'un önemli sanatçıları arasında yer almaktadır. Deaunay'a ait birçok eser Sturm Galeri'de sergilenmiştir. Bununla beraber, sanatçı galeride bir de kişisel sergi açmıştır. Bu sayede çok sayıda çalışmasını sergileme firsatı bulmuştur. Bilindiği üzere sanatçı Orfizm ${ }^{1}$ akımının yaratıcılarındandır. Orfist anlayışla yaptığı resimleri oldukça renkli bir üslupla oluşturmuştur. Kullandığı bu çok renkli paletiyle oluşturduğu valör değerlerini tuvaline cesurca yansıtır. Buna karşın sanatçının Walden Portresi’nde bu anlayışın izleri görülmemektedir (Resim 17). Tuval üzerine yağlı boya olarak resmettiği çalışmasında, ağırlıklı olarak kahverengi ve tonlarının kullanıldığı görülmektedir. Resmin tam anlamıla bitirilmemesi de dikkat çekicidir. Bu bitmemişlik çalışmayı adeta büyük bir yağlı boya eskizine dönüştürür. Bir diğer dikkat çekici nokta detaylı anlatımın portrede yoğunlaşmasıdır. Sanatçının resmin alt kadrajına doğru ayrıntıdan kaçındığı görülür. Detaylardan yoksun el ve elinde tutuğu şey belli belirsiz çizilmiştir. Kim bilir bu şey belki de o ayki Sturm Dergisi'dir.

“Orfizm/Orfik Kübizm: Robert Delaunay ve eşi Sonia Delaunay- Terk'in 1912 yılında başlattı̆̆ kübist akım. Bu ad, şair Guillaume
Apollinaire tarafindan seçilmiştir. Ancak Delaunay, orfizm yerine 'simultaneizm'terimini kullanmayı tercih etmiştir.” (Keser, 2009, s. 240) 


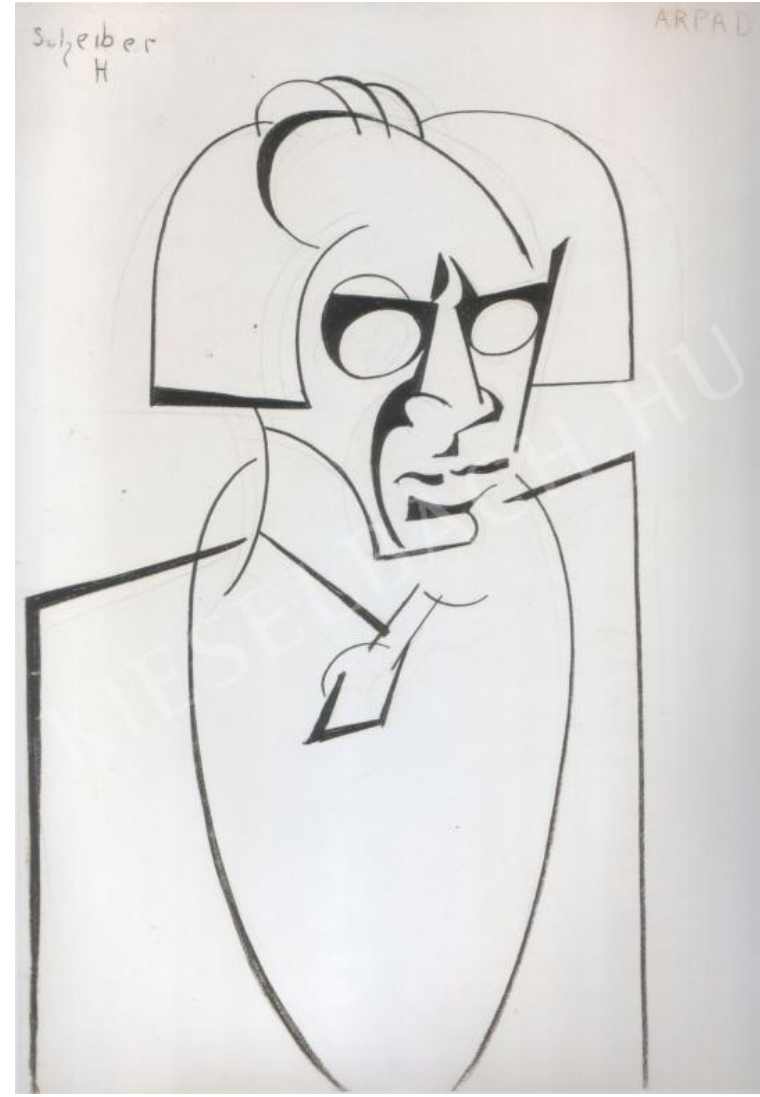

Resim 18: Hugó Scheiber, Herwarth Walden Portresi, 1925.

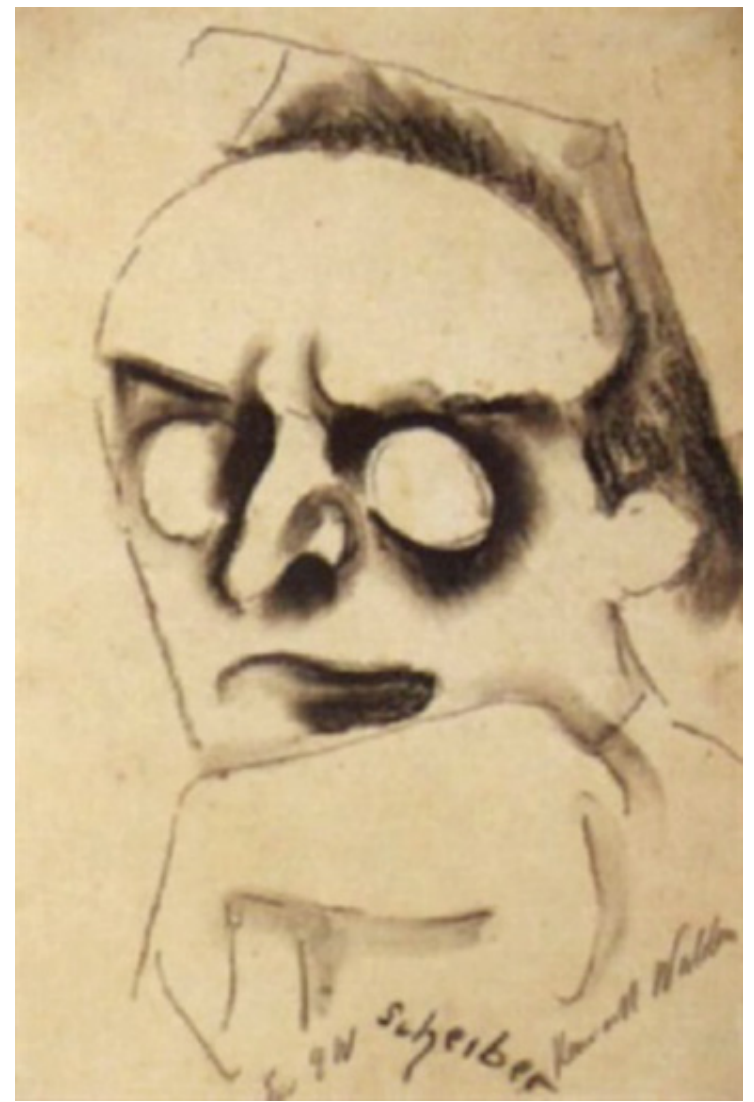

Resim 19: Hugó Scheiber, Herwarth Walden Portresi, Kağıt üzerine füzen, 27,5 x $24.4 \mathrm{~cm}, 1924$.

Resim 18 ve 19'da Macar ressam Hugó Schreiber'ın çizdiği iki adet Walden Portresi yer almaktadır. Resim 18 'de sanatçının düz keskin çizgiler kullanarak figürü geometrik bir formla oluşturduğu görülür. İnce ve kalın çizgilerle oluşturduğu kompozisyonda kullanılan kalın çizgilerin aynı zamanda 1şık gölgeyi oluşturmak için kullanıldığı gözlenir. Çalışmada malzeme olarak füzen ve kalem beraber kullanılmıștır. Siyah ve beyaz zıtlığı ile oluşturulan figürün ifadesindeki sertlik dikkat çekicidir. Sanatçının diğer çalışmasının da benzer bir anlayışla yaptığı görülür. Desenler arasında bir yıllık bir fark vardır. Sanatçının 1924 yılında gerçekleştirdiği Walden Portresi'nde (Resim 19) daha serbest bir teknik kullandığı görülür. Bu serbestliğin tek başına kullandığı füzen malzemesinin olanaklarından kaynaklandığını söylenebilir. Her iki portrede de kullanılan 1şık gölge yaklaşımı benzerlikler taşır. Füzenle oluşturulan portrede malzeme sayesinde daha yumuşak ton değerleri ortaya çıkmıştır. 


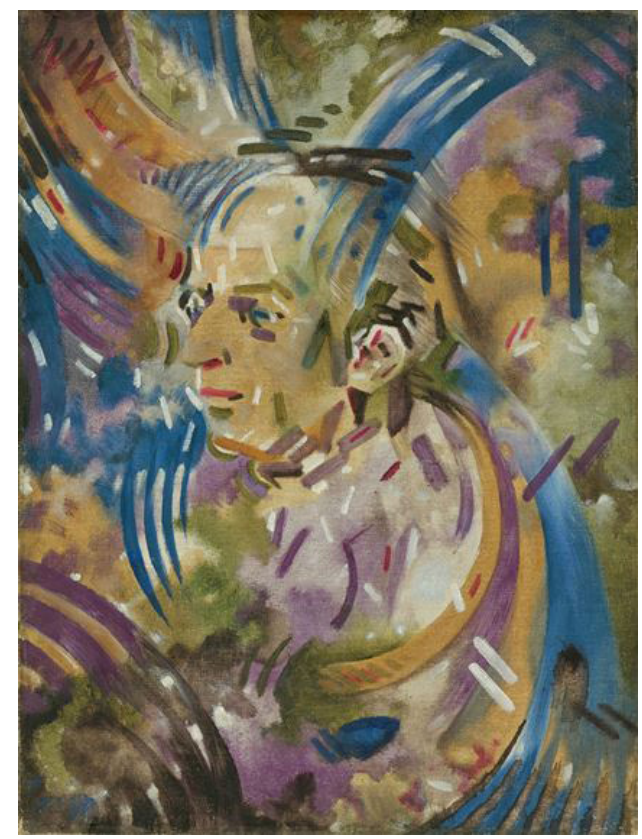

Resim 20: William Wauer, Herwarth Walden Portresi, 65 x $49 \mathrm{~cm}$, Tuval üzerine yağlıboya.

William Wauer'in Walden Portreleri arasında bir resim ve heykel çalışması bulunmaktadır (Resim 20-21-22). Sanatçının genellikle çalışmalarında kullandığı hareket etkisi Walden Portreleri'nde de görülmektedir. Tuval üzerine yağlı boya tekniğiyle çalıştığı portrede mekân duygusu kaybolmuştur. Onun yerine figürü çevreleyen bir renk kompozisyonu oluşturulmuş ve portre onun merkezine yerleştirilmiştir. Adeta figür soyut bir sarmalın ortasında belirmiştir. İzleyiciye tıpkı bir kaleydoskoptan bakar hissi vermektedir (Resim 20).

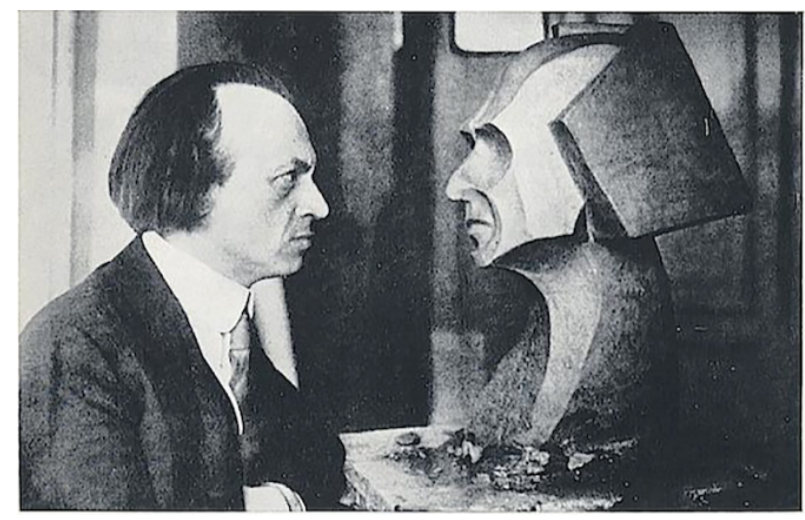

Resim 21: Herwart Walden ve sanatçı William Wauer'in Walden'i yaptığı büstü, 1918 .

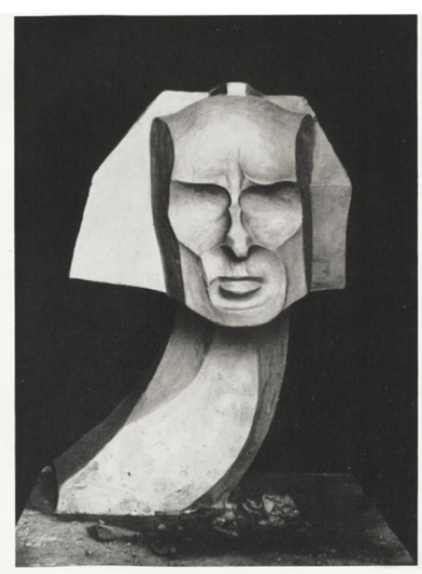

Resim 22: William Wauer, Herwarth Walden Büstü, Uzunluk 53,5 cm x Genişlik $37 \mathrm{~cm}$ x Derinlik $34 \mathrm{~cm}$, Bronz, Berlin Ulusal Müzesi, 1917.

Sanatçı William Wauer'in bir diğer çalışması, 1917 yılında yaptığı Herwarth Walden büstü oldukça dikkat çekici bir Walden portre örneğidir (Resim 21-22). Lionel Richard, heykelde dişavurumculuğun tanımının kesin çizgilerle belirlenmediğinden ve iki eğilimin var olduğundan söz etmektedir. $\mathrm{Bu}$ 
eğilimlerden ilkini 'kuralların sorguya çekilmesi' olarak ifade ederken, diğerinin ise 'gerçeklikten saptırılmış, soyut, ama yine de sanatçının içsel yaratma gereksinmesi duygusuna yakından bağlı biçimlerin yoğun anlatımını kapsar' şekilde olduğunu söyler (Richard, 1991, s. 110). Richard, sanatçı Wauer'in ikinci eğilime yakınlığından bahsederken sanatçının heykel anlatımında tamamen 'özerk bir anlatım dili' kullandığına da dikkat çekmektedir (Richard, 1991, s. 110).

William Wauer, Walden büstünü keskin çizgilerle planlara ayırarak oluşturmuştur, sanatçının oluşturduğu bu keskin hatlı sağlam yontu kütlesinin kaide kısmını oluşturan uzun boyun yapısı heykele yumuşak bir hareket kazandırmaktadır. Bu hareket duygusuyla büstün duygu ifadesi birleştiğinde heykel izleyicide güçlü bir etki yaratmaktadır. Nitekim Lionel Richard (1991, s.115), sanatçının çalışmalarında "içsel bir devinimi köklü bir biçimde dışa vurmayı aradığını" söyler. Sanatçının Walden portresinde de bu arayışın izlerini bulmak mümkündür.

\section{Sonuç}

Portre Sanat, Sanat Tarihi içinde her zaman önemli bir yere sahip olmuştur. Dönemsel olarak yapılma sebepleri değişikliğe uğrayan portrecilik, 20. yüzyılda karşımıza bambaşka bir tavırla çıkar. Birebir anlatımdan soyutlamaya giden yolda, sanatçılar tarafindan yorumlanan özgün eserler yaratılmıştır. Bu dönemde avangard sanat kimi çevrelerde benimsenmese de döneme yeni bir soluk ve heyecan getirmiştir. Nitekim yaratılan eserler duygu, düşünce ve yanılsama gibi soyut kavramlara temellenmektedir. Çalışmanın özelinde bu tavırla üretim yapan Der Sturm Sanatçılarının gözünden Herwarth Walden merkezli portre eserleri incelenmiştir. Bu eserler bu anlamda ilk kez bu makalede yer almıştır.

Walden yaşamı boyunca sanatla dolu bir hayat yaşar. Avangard sanata ve sanatçılarına yarattı̆̆ 1 görünürlük ortamı önemlidir. Zira o dönemde yeni sanatı destekleyen az insan vardır. Sanatçıların Herwarth Walden'le kurdukları güven ilişkisi çalışmalarının başarılı olmasında, dönemin sanat ortamında ses getirmesinde etkili olmuştur demek yanlış olmayacaktır. Bununla beraber Walden sanatçların çalışmalarının satışından sorumlu bir aracı olmaktan çok onlara önemli başarılar kazandıran bir destekçi durumundadır. Bu sayede sanatçılarla birlikte Walden'de önemli başarılar sağlamıştır. Walden Portreleri'nin çoğunun Herwart Walden yaşarken yapılması da önemli bir noktadır. Zira bu durumu sanatçıların Walden'nin başta Alman Dışavurumculuğu olmak üzere diğer avangard hareketlerine ve bu anlayışla üretim yapan sanatçılara olan desteğine ve inancına olan saygısı olarak nitelendirebiliriz. Walden portrelerinde her sanatçının kendi özgün yaklaşımıyla çok farklı ifade ve anlatım özelliklerine sahip portreler ürettikleri görülür. Bu üslup ve yaklaşım Walden'in özgün karakteriyle birleşmektedir. Sanatçıların değişik dönemlerde farklı medyumları kullanarak yorumladıkları Walden portreleri, Herwarth Walden'i anlamak, dönemsel olarak sanatçıyı ve sanatçının dünyasını gözlemleyebilmek açısından önem taşımaktadır. Bu sebeple portrelerin her biri tarihsel açıdan da belge niteliğindedir. Diğer bir yandan da dönemin avangard sanatını anlamak için de önemli ve değerli kaynaklardır.

\section{Kaynakça}

Chipp, H. B., (1968). Theories of Modern Art- A Source Book by Artists and Critics. Londra: University of California Press.

Dick, R., (2012). Else Lasker- Schüler- Franz Marc: Eine Freundschaft in Breifen und Bildern. Mit sämtlichen privaten und literarischen Brifen. München: Prestel Verlag. 
Hülsen-Esch, A. v., (2011). Das Unternehmen Der Sturm und Herwarth Walden als Unternehmer. Prof. Dr. Andrea von Hülsen-Esch ve Dr. Gerhard Finckh (Ed.) Der Sturm Band II: Aufsätze (s. 201-225). Wuppertal: Von der Heydt Museum.

Keser, N., (2009). Sanat Sözlüğü. Ankara: Ütopya Yayınevi.

Richard, L., (1991). Ekspresyonizm Sanat Ansiklopedisi, (B. Madra, S. Gürsoy, İ. Usmanbaş, çev.). İstanbul: Remzi Kitabevi.

Neitzel, L. H. (1913). Was ist Der Sturm. Herwarth Walden (Ed.) Einblick in Kunst: Expressionismus, Futurismus, Kubismus (s. 153-154). Berlin: Verlag Der Sturm.

Schreyer, L. \& Walden, N., (1954). Der Strum Ein Gedenkbuch An Herwarth Walden Und Die Künstler Des Sturmkreises. Baden-Baden : Woldemar Klein Verlag.

Schreyer, L., (1956). Erinnerungen an Sturm und Bauhaus. München: Albert Langen Georg Müller Verlag $\mathrm{GmbH}$.

Sheppard, R., (2009). Alman Dışavurumculuğu. Modernizmin Serüveni (s. 239-249) içinde. İstanbul: Alkım Yayınları.

Vierhaus, R., (2008). Deutsche Biographische Enyzklopädie. München: K.G. Saur Verlag.

Walden, H., (1910). Zwei Worte. Der Sturm Kultur und Die Künste Wochenschrift Erster Jahrgang, Nummer 1 (s.1). Berlin: Verlag Der Sturm.

Walden, H., (1913). Erster Deutscher Herbstsalon. Berlin: Verlag Der Sturm.

Walden, H., (1924). Einblick in Kunst: Expressionismus, Futurismus, Kubismus. Berlin: Verlag Der Sturm.

Walden, N., (1963). Herwarth Walden. Mainz : Bei Florian Kupferberg Verlag.

\section{Görsel Kaynakça}

Resim 1: Walden N., 1963. Nell Walden Fotoğraf Arşivi.

Resim 2: Walden N., 1963. Nell Walden Fotoğraf Arşivi.

Resim 3: Schreyer L. \& Walden N., 1954.

Resim 4: Der Sturm Dergisi, 22. Say1, 1910, s.175.

Resim 5: Walden N., 1963. Nell Walden Fotoğraf Arşivi.

Resim 6: Walden N., 1963. Nell Walden Fotoğraf Arşivi.

Resim 7: Walden N., 1963.

Resim 8: Walden N., 1963.

Resim 9: Walden N., 1963.

Resim 10: https://www.deutschlandfunkkultur.de/ausstellung-gegen-die-etablierte-moderne.932. de.html?dram:article_id=262214) (Erişim Tarihi: 19.02.2019). 
Resim 11: http://www.artnet.com/artists/edmund-kesting/bildnis-herwarth-waldennTyL15OaO2Wkuwc8eEFbGw2) (Erişim Tarihi: 19.02.2019).

Resim 12: Der Sturm Dergisi, 2. y11, 99. Sayı,1912, s.78.

Resim 13: Der Sturm Dergisi,15. y11, 3. sayı Kapağı, 1924.

Resim 14: https://www.wikiwand.com/de/Herwarth_Walden (Erişim Tarihi: 07.03.2019).

Resim 15: https://www.bukowskis.com/en/auctions/553/84-john-jon-and-portratt-av-herwarthwalden?from_language $=$ en (Erişim Tarihi: 07.03.2019)

Resim 16: https://www.wikiwand.com/en/Herwarth_Walden) (Erişim Tarihi: 04.02.2019).

Resim 17: https://www.dw.com/en/else-lasker-schüler-my- heart/a-45434177 (Erişim Tarihi: 04.02.2019).

Resim 18: https://www.kieselbach.hu/exhibition-artwork/scheiberexhibition/portrait- ofherwarthwalden-4615 (Erişim Tarihi: 04.02.2019).

Resim 19: https://www.artnet.com/artists/ hugóscheiber/porträt-herwarth-walden vpZiWZnMC85dEK7uGFnaTg2 (Erişim Tarihi: 04.02.2019).

Resim 20: https://www.mutualart.com/Artwork/Portrat-Herwarth-Walden/BA2E1BF984D30F10 (Erişim Tarihi:04.02.2019).

Resim 21: Walden N., 1963.

Resim 22: Schreyer \& Walden N., 1954. 